\title{
GEOTHERMAL AQUACULTURE:
}

\section{A GUIDE TO FRESHWATER PRAWN CULTURE}

\author{
Geo-Heat Utilization Center \\ Oregon Institute of Technology \\ Klamath Falls, Oregon
}

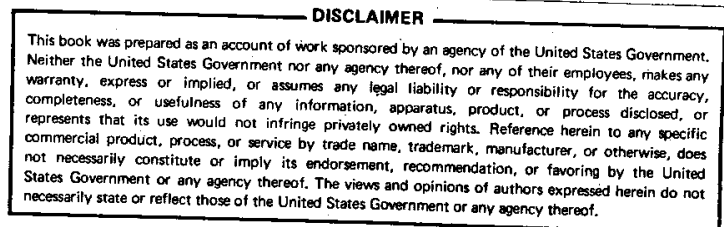

by

Annette Hayes and William C. Johnson

May. 1980 


\section{DISCLAIMER}

This report was prepared as an account of work sponsored by an agency of the United States Government. Neither the United States Government nor any agency Thereof, nor any of their employees, makes any warranty, express or implied, or assumes any legal liability or responsibility for the accuracy, completeness, or usefulness of any information, apparatus, product, or process disclosed, or represents that its use would not infringe privately owned rights. Reference herein to any specific commercial product, process, or service by trade name, trademark, manufacturer, or otherwise does not necessarily constitute or imply its endorsement, recommendation, or favoring by the United States Government or any agency thereof. The views and opinions of authors expressed herein do not necessarily state or reflect those of the United States Government or any agency thereof. 


\section{DISCLAIMER}

Portions of this document may be illegible in electronic image products. Images are produced from the best available original document. 
The aquaculture of the Malaysian prawn is not really a science as some would tend to believe. It is actually an "art." Science has its influences in the culture of this tropical crustacean, but not much is known about its biology that can be directly applied to a comercial operation. A prawn farmer need not be. a scientist in order to succeed. Yet, he must be dedicated, observant, and patient. Dafly vigil over the prawns and ponds will make one aware of when changes occur. A good farmer will recognize these changes as being for the better or for the worse, and will know the course of action to take. Much of becoming a success in the prawn business lies behind experience, and, perhaps, luck. A word of caution--prawns can indeed be a moneymaker, but don't expect to get rich from it as it is often hard and frustrating work.

This project is sponsored by the Pacific Northwest Regional Commission, Vancouver, Washington. 


\section{Chapter I: Introduction}

\section{Biology}

The giant Malaysian prawn, Macrobrachium rosenbergii, can be found naturally in the tropical regions of Southeast Asia. It inhabits freshwater streams, rivers, : and ponds, but can survive in brackish water. A mature female is believed to migrate downstream to an estuary where her eggs hatch into free-swimning pelagic 1arvae. The larvae develop in the brackish water, going through eleven larval stages for 18-45 days before metamorphosing into benthic post-larvae (PLs), Figures 1 and 2. The PLs then migrate upstream to freshwater.

In warm water $\left(27^{\circ}-30^{\circ} \mathrm{C}\right)$, prawns can reach maturity in $5-7$ months. Males, characterized by their large claw-like pinchers, grow faster. A female's growth rate will slow down as she reaches maturity. Most of her energy will go into spawning instead of to weight conversion. Female prawns will spawn several times a year depending upon environmental and temperature conditions. The number of eggs produced varies with the size of the female and will range between 60,000 and 100,000 (Ling, 1969). Newly fertilized eggs, a bright orange, are placed on the female's pleopods. They incubate here for 21 days, undergoing a color change to dark brown or gray just before hatching. The larvae usually hatch at night and can live in freshwater for a short while (some as long as three days), but must be in brackish water in order to survive and develop further.

History

The basic biology of this prawn was studied by S. W. Ling in 1961, in Penang, Malaysia. Dr. Ling discovered that salinity was the key to larvae development. In 


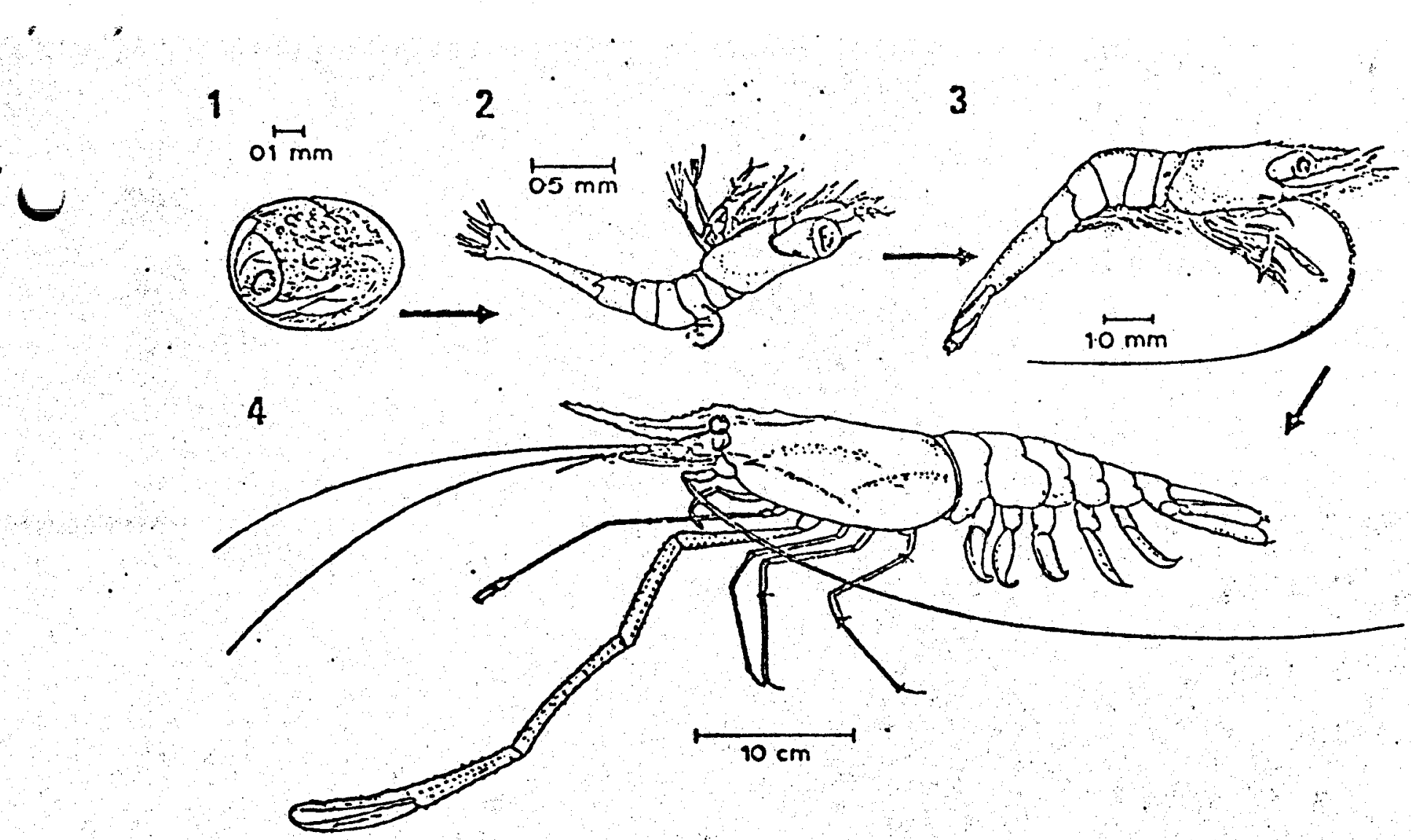

Figure 7.-The life cyele of a cridean prawn, Nacrobrachium sp., 1, egg, 2, larva; 3, post-larva, 4. adult (from Forster and (Vickins, 1972).

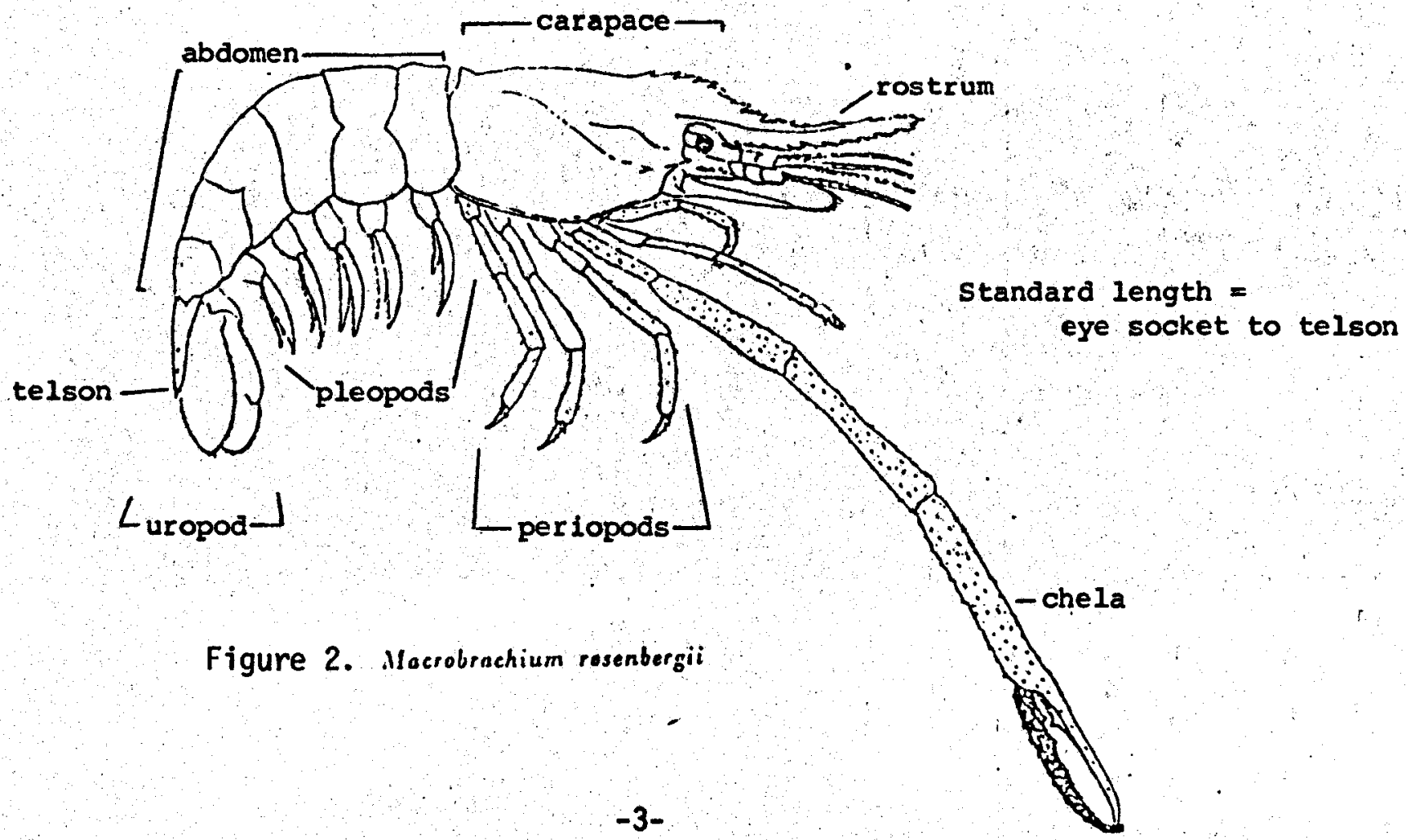


1965, Takuji Fujimura, of the Hawaii Fish \& Game, obtained broodstock from Malaysia and perfected mass-culture larval rearing techniques. By 1970, 1 hector (1.5 acres) of pilot farms existed in Hawaif (Fujimura, 1974). This number has expanded exponentially, and the original broodstock from Malaysia has provided seed stock for farms and research institutions all over the world.

\section{Geothermal Application}

Although prawn aquaculture is basically limited to tropical areas, its range can be expanded through the use of geothermal water or industrial warm water effluent. The Oregon Institute of Technology (OIT), in Klamath Falls, Oregon, uses geothermal water for space heating and uses its wasted geothermal water for prawn ponds. The water is pumped from the campus wells at $97^{\circ} \mathrm{C}$ and is used to heat more than a halfmillion square feet of classrooms and laboratories. It is then discharged into an open ditch at $56^{\circ} \mathrm{C}$. The wasted water is of class 1 irrigation quality and is used for the aquaculture facility. An electric temperature controller regulates the water inflow to keep the pond temperature at $27 \pm 1^{\circ} \mathrm{C}$, despite ambient temperatures below freezing. The school's experimental ponds have shown that geothermally heated water is ideal for prawn aquaculture (Johnson). It has been found that prawns reach marketable size faster in a controlled environment than in nature. A cormercial farm near the OIT campus has shown the potential feasibility of raising prawns in a lessthan-tropical climate. 


\section{Chapter II: Pond Management}

The basic principles and concepts of pond management are simple biological and ecological phenomena. It is their interaction which makes the theory of pond husbandry complex.

\section{Design and Construction}

A pond relying on geothermal water to maintain a tropical environment of $22^{\circ}-30^{\circ} \mathrm{C}$ must be designed with the necessary hardware to assure that this temperature does not fluctuate appreciably. Mechanical fallure or error could mean the loss of time and income.

The basic prawn pond is constructed contrary to prawn behavior. Ease of harvesting and management are taken into consideration instead, since these are the areas of high (labor) costs. The following are some important features of prawn ponds:

(1) Earthen ponds are good biological systems. Concrete raceways and plasticline ponds are expensive, and, in many cases, too sterile.

(2) The bottom of the pond should be flat because irregular surfaces and rocks interfere with seine harvesting. In raceway ponds, a gradual slope toward the outlet would facilitate draining.

(3) The slope of the pond banks is a 3:1 grade. This gentle slope slows erosion and makes it easier to get in and out of the pond. The water level is 0.3 meters below the top of the berm. Grass planted in this area deters erosion and provides shelters for PLs, berried females, and newly-molted t animals. The water level can be lowered below the grassline at harvest time. 
(4) The width of the berms between ponds should be 3-4 meters to allow for vehicular traffic.

(5) A pond should be 1 to 1-1/2 meters deep and have a good phytoplankton bloom to prevent sunlight from shining on the bottom of the pond. The lack of sunlight will deter the growth of benthic aquatic weeds which can interfere with the seine harvesting.

(6) The water should flow out through a sluice gate system, figure 3, which allows for rapid regulation of the water level and/or flushing.

(7) Plumbing for prawn ponds should be black iron because of the possibility of toxicity problems or plastic PVC or CPVC pipe.

\section{Stocking}

Newly constructed ponds must be "seasoned" before they can be stocked with PLs. The application of small amounts of fertilizer may be necessary to start a phytoplankton bloom. A good source of balanced (N-P-K) fertilizer is manure. Once a bloom gets started, further fertilization is not necessary and may even be detrimental. Stirring the mud at the bottom of the pond will often increase algae productivity.

Mosquito fish, gambusia, can be introduced into ponds to control the dragonfly nymph population. (Dragonfly nymphs have large mouths and can easily eat many PLs.) The number of gambusia is regulated as the larger prawns forage on them.

If grass has not been planted before the introduction of the PLs, temporary shelters such as hardwood brushes should be placed around the perimeter of the pond. These are to be removed before they decay and after the grass is planted.

A new pond may have minor seepage problems, requiring a higher inflow rate to maintain the water leve1. It may take some time for mud and organic wastes to 
completely seal the pond. However, it is not necessary to wait for the pond to seal before putting the PLS in.

Prawns are aggressive, territorialistic, and notoriously cannibalistic. The ideal stocking rate is one prawn per square foot $(1: 1)$, but in a commercial growout system based on a year-round harvest and a once a year stocking, a good stocking rate is 1.5:1. Prawn density may be increased slightly by adding more shelters, but excessively high densities will overload the ecosystem. In such a case, prawns will grow only to a certain size or until the pond reaches its critical maximum biomass. Also, overloading will require more oxygen than the system is capable of producing, and thus suffocate large numbers of the prawns. This is nature's way of limiting the biomass to its natural level.

\section{Daily Pond Maintenance}

Pond maintenance is not 1 imited to feeding the prawns daily. It is more demanding, and should never become a routine. Careful observation of each pond (as being a separate ecosystem from another) will warn a farmer of disaster before it happens. It is easy to fall into a routine of feeding and to become skeptical that there are any prawns left in the pond. This doubt can be erased by shining a flashlight in the pond at night. The reflection off the eyes of the prawns will affirm their presence. Additionally, the farmer should occasionally seine with a small mesh net to have an idea of the average size and/or growth rate of the prawns in the pond. In geothermal systems where water temperature regulation is critical, he should monitor the inflow of the water and pond temperature faithfully.

Phytoplankton density (which is related to oxygen production) is another factor in maintenance. It can be measured with a Secchi disc or white plate. If it disappears in less than $30 \mathrm{~cm}$ in depth, it indicates a good phytoplankton bloom. A lower number calls for an increase in water flow for flushing; a higher number for 
DESIGN OF OUTLET FOR PONDS

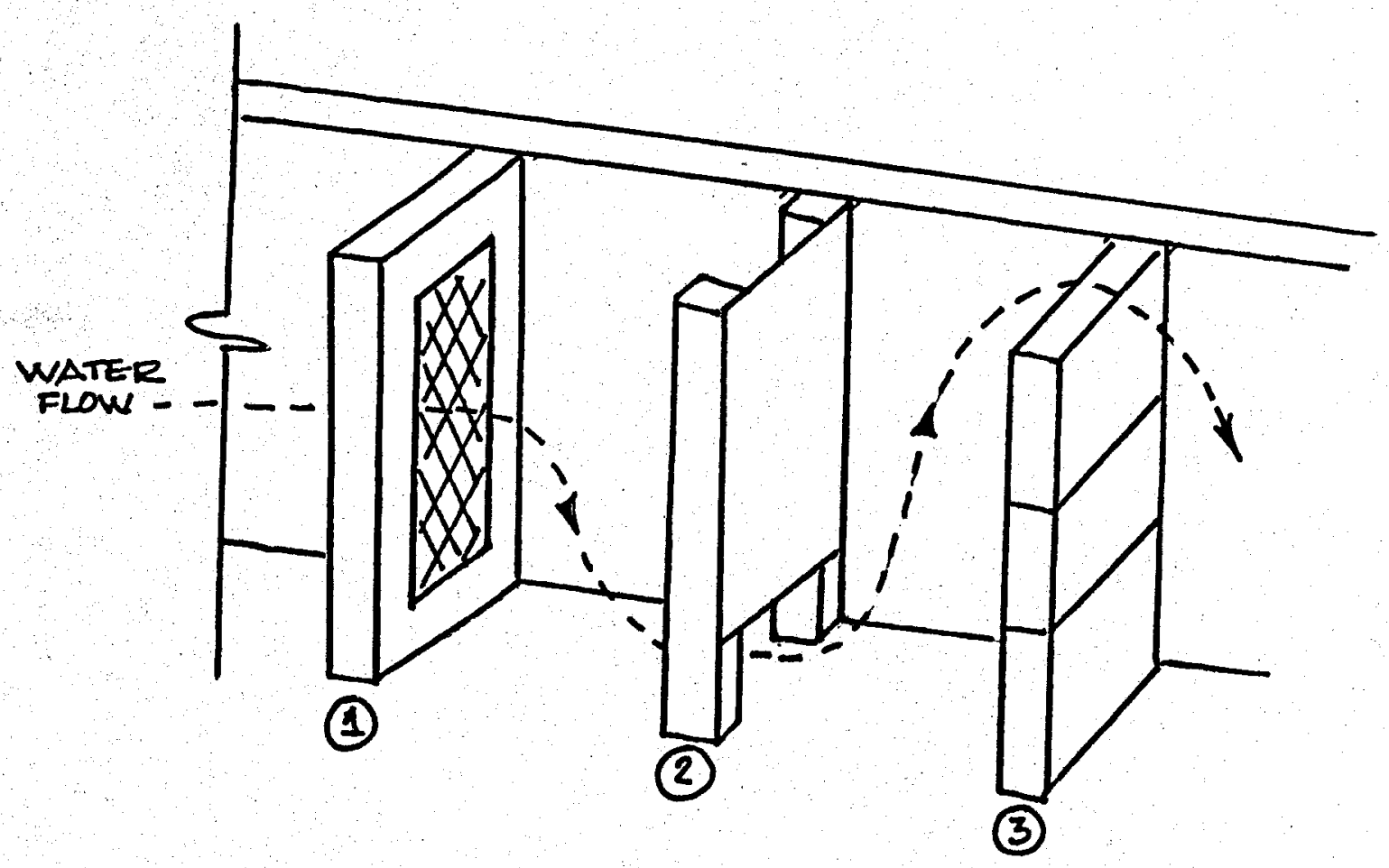

Figure 3.

FEATURES:

(1) SCREEN - TO BE INTERCHANGEABLE, DEPENDING ON SIZE OF PRAWNS

(2) BARRIER, WITH BOTIOM CUT OUT, SO THAT WATER EXCHANGE WILL COME FROM THE BOTTOM OF THE POND, WHERE DISSOLVED OXYGEN IS LOWEST

(3) BAFFLES. A SERIES OF BOARDS PLACED IN SUCH A MANNER SO AS TO MAIMTAAM WATER HEIGHT IN POND

$-8-$ 
DESIGN OF OUTLET FOR PONDS - CONT

FUNCTION OF FEATURES:

(1) SCREEN - WILL KEEP PRAWNS IN THE POND. BEWARE OF leAves, ALGAE, AND OTHER DEBRIS WHICH MAY CLOG THE SCREEN AND CAUSE $\triangle N$ OVERFLOW OF WATER. THE SCREEN MESH MAY BE VARIED, FROM WINDOW I SCREEN (FIBERGLASS) WHEN PL'S ARE STOCKED, to A $1 / 4$ " SCREEN WHEN ONLY ADULTS ARE IN THE POND.

(2) BARRIER -MAY BE SIMPLY CONSTRUCTED OF PLYWOOD ON TWO POSTS. IN THE NORMAL COURSE OF WATER EXCHANGE IN THE POND, IT IS BEST TO REMOVE OXYGEN -POOR WATER NEAR THE POND BOTTOM THAN TO TAKE OXYGEN-RICH WATER FROM THE SURFACE. THE BARRIER DESIGN LOWS FOR THIS.

(3) BAFFLES - THE BAFFLES KEED THE WATER IN THE POND. TO LET WATER OUT OF THE POND, AS IN DRAINING OR FLUSHING PROCESS, THE BOARDS $\triangle R E$ TAKEN OUT. TO EXPIDITE THE WATER FLOW IN A DRAIN-DOWN, THE BARRIER (2) MAY BE TAKEN OUT, BUT IS NOT NECESSARY.

Figure 3 (cont.)

$-9-$ 
a decrease. The color of the water indicates the predominant algae species present. A green algae is preferred because of the amount of oxygen it produces in photosynthesis and because of its stable production cycle. Diatoms, which turn the water yellow-brown, are also desirable. Blue-green algae cycles fluctuate greatly are not as desirable for some species may release toxins into the water.

The production of sufficient oxygen for the system is an important concept of pond management. If the amount of dissolved oxygen (DO) is low, the prawns and fish will go into stress. This behavior pattern would most likely be seen in early morning before sunrise when $D O$ Leveis are lowest. The prawns circle the pond at the surface looking for oxygen. As soon as stress behavior is observed, whether it is caused by low DO, measure units must be taken to assess the problem. Rapid flushing (or mechanical aeration) should alleviate the stress symptoms within a few hours. A good farmer will learn to recognize the events which could lead to stress days before it happens and will take precautionary measures, i.e., reduce the algae mass in the pond.

Excessive feed can cause stress symptoms if the uneaten feed decays and cannot be broken down fast enough by the bacteria in the ecosystem. For this reason, it is crucial to not overfeed. Prawns will eat the natural foods in the pond, such as worms, bugs, fish, etc. Applied feeds are only supplemental to obtain faster growth in a commercial operation. Chicken brotler starter or turkey starter (26\% protein) have done well as a prawn food. In Hawaii, a prawn pellet formula is being used. This formula is basically a standardized chicken feed recipe without the antibiotics used for poultry.

The amount of food that prawns will consume is proportional to their body weight. A new pond is fed one kilogram per acre per day and increases to $10-20 \mathrm{~kg}$. When the pond is in full production (Fujimoto, 1977). Most of this feed, in the beginning, 
feeds the fish and builds up the productivity of the pond. But each pond is different; the growth rate of the prawns will vary, and so will the rate of feeding. To insure against overfeeding, routine checks on the pond should indicate whether to increase or decrease the daily ration. Observe for uneaten food, or get in the pond and kick up the mud. If traces of food remain the next day, decrease the amount of food.

Less frequent maintenance chores include the control of pond vegetation. Dense areas of coarse grasses and weeds in the pond will hamper harvesting. Vegetation on inaccessible slopes can be sprayed with the herbicide, Roundup, without harming the prawns.

Occasional predatory animals will be attracted to the abundance of food in the pond. Frogs have enormous appetites and are known to eat large prawns. Herons crave these delicacies, eating soft-shelled ones whole, and piercing through harder ones. Carnivorous fish should be kept out of the ponds.

\section{Harvesting}

The theory behind a harvesting strategy is NOT to keep the market supplied, nor to make money. Harvesting frequency is used to regulate the prawn biomass for maximum production. Juvenile prawns grow at approximately the same rate for the first few months. Some then grow faster (fast growing males have golden claws) and suppress the growth of others. Fujimure describes this as the "bul1-runt" phenomena (Fujimura, 1974). A periodic culling of the larger ones with a seine net provides the undersized animals with more room to grow. The culling may occur every 3-4 weeks. In this method, a $5 \mathrm{~cm}$ (2-inch) mesh seine net is moved through the pond, capturing animals $11.5 \mathrm{~cm}$ (eye socket to telson) or larger. If many smaller prawns are taken to meet a market quota, then the number of prawns left in the pond would decrease and thereby curtail the maximum available production from the pond. Soon there are no 
market-sized prawns left in the pond, the cost of restocking is $\$ 50 /$ thousand PLS, and that pond produces no income until the PLS reach maturity.

A variation of the seine net harvesting (three men can harvest a one-acre pond in 45 minutes) is the mechanical harvest. This method is most useful in a raceway pond. The basic design consists of a rigid bar to hold the net open. The bottom of the net conforms to the irregularities of the pond bottom. A tractor pulls the two ends of the net along the length of the pond. The seine harvesting method is used in continuous culturing systems.

If only one crop is to be raised per season, then a batch harvest may be more convenient. In batch harvesting, the pond is drained and all prawns, no matter how smal1, are harvested at the end of the growing season. This method of harvesting can also be used in nursery ponds where PLs are stocked heavily into a small pond. When there is a noticeable interaction between prawns in the nursery ponds, the number of juveniles can be divided into several grow-out ponds.

Electro-shocking, where an electric current is introduced into the pond stunning the fish and prawns, can be used in collecting a few animals or berried females. This method is not effective for a selective harvest of prawns, but is good for random sampling if $D C$ current is used.

Marketing

An important key to a successful prawn operation is being able to market the quality prawns. Improperly processed prawns will be undesirable because the meat is soft and mushy. The muscle fibers in the tails of near-senescent prawns shrink from the shell and are tough. Better processing and handling methods should be employed to insure a firm meat quality, prolong the shelf-life, and provide a product attractive to the customers. The following are some of the commonly used methods of processing prawns:

(1) Live prawns: Prawns are transported to market in an insulated tank in 
clean, cool aerated water. Live prawns may demand a higher price in some communities.

(2) Blanching: Prawns are dipped in hot water, cooled, then packed in ice. Blanching prolongs the shelf-life to a week under refrigeration by killing external bacteria and by stopping the enzyme activity which breaks down the muscle tissue to make it mushy.

(3) Flash-freezing: Each prawn is individually quick frozen. This method yields a good quality product, but packaging presents a problem. Appendages become brittle and fall off, resulting in weight loss.

(4) Ice freezing: Freezing in a block of ice retains water in the muscle fibers and prevents weight loss. The block of ice must freeze before deterioration begins. It is also easier to package this product in shapes and sizes suitable for retail outlets.

It may be necessary to initiate a consumer education program to distinguish prawns from shrimp. To get the consumer aware of the product, a promotional program may be initiated to demonstrate how to store, clean, cook, and eat the prawns. Such a program would be expanded as the demand for the aquaculture product increases.

\section{Pond Site Selection}

Prawn aquaculture may look impressive based upon the economics and expected cash inflow, but an improper site for the ponds could be costly. Consideration must be given to the following areas before the decision is made to start a prawn operation:

(1) Water quality and source. A chemical analysis on the water or a bioassay is necessary to determine whether the water quality is good enough for culturing prawns. It is also essential to determine from the temperature capacity and the maximum available flow rate the best size of each pond which will maintain a temperature of $27^{\circ}-30^{\circ} \mathrm{C}$. Once these figures are obtained, 
it is possible to estimate the total acreage needed for the farm. The final and most important step is to decide whether an operation of that size will be profitable.

(2) Type of soil. Clay loam soil is the best. The soil must be compactable, must retain water, and have few rocks (to tangle in the harvest net). Plastic liners may be used, but these are costly and will eventually deteriorate, defeating its original purpose, When new, plastics may also leach out toxic materials.

(3) Location of market or processing plant. These should be close to the farm to reduce the deterioration in the quality of the product when transported from the pond.

(4) Previous history of the selected site. The land may have residual herbicides or pesticides from its previous use. These would kill the prawns or the prawns could carry them to the consumer. Neither condition is desirable. 


\section{Chapter III: Hatchery--Larval Culture}

Larval culture had been unsuccessful until Ling discovered the requirement for brackish water (12-18 parts per thousands sea water) in larval development. Hatcheries now follow the basic mass-rearing techniques of Fujimura. Under ideal temperatures $\left(27^{\circ}-29^{\circ} \mathrm{C}\right)$ larvae metamorphose into PLs in $18-45$ days. A PL looks like a miniature sized adult. There is no clear distinction between a PL and a juvenile the latter term usually referring to a PL over a month old or to a young prawn of a larger size.

\section{Hatchery Design and Function}

A greenhouse-type structure will utilize some solar energy and will permit yearround larval culture, especially if geothermal water is used for space heating and if heat exchanger coils are placed in larval rearing tanks.

Larger hatcheries usually have static culture systems where water is periodically changed. Modifications for a flow-through system include a standpipe or overflow pipe. A screen keeps the larvae inside the tank (Figure 4). These systems may or may not use "green water" as the culture media. Phytoplankton-rich "green water" acts as a buffer, taking some toxic nitrogen compounds and ammonia out of the water. A recirculated culturing system is usually used for smaller or research hatcheries. In order to conserve water (such as that which is made from the commercial sea-salt mix, Instant Ocean), the water is filtered and buffered, so it can be used again. Partial water changes must be made occasionally when the nutrient load increases.

Excretion and food decay produce high amounts of amonia, nitrates and nitrites which can be toxic to larvae. These levels of toxicity are reached faster at warmer 
FLOW THROUGH (STATIC) SYSTEM:

$\infty$
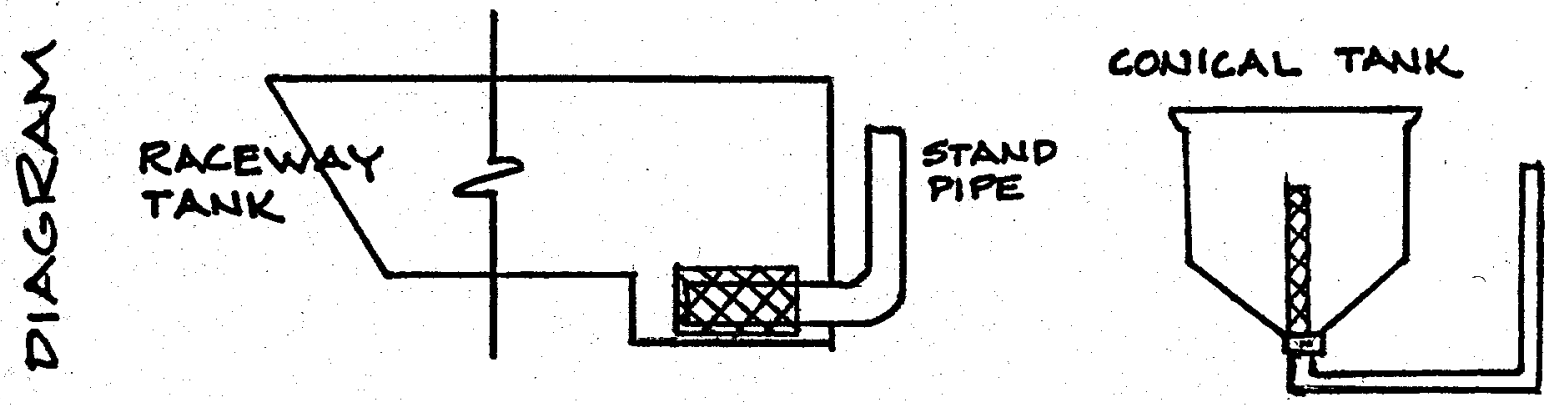

RECIRCULATED SYSTEM:

COMPRESSED AIR

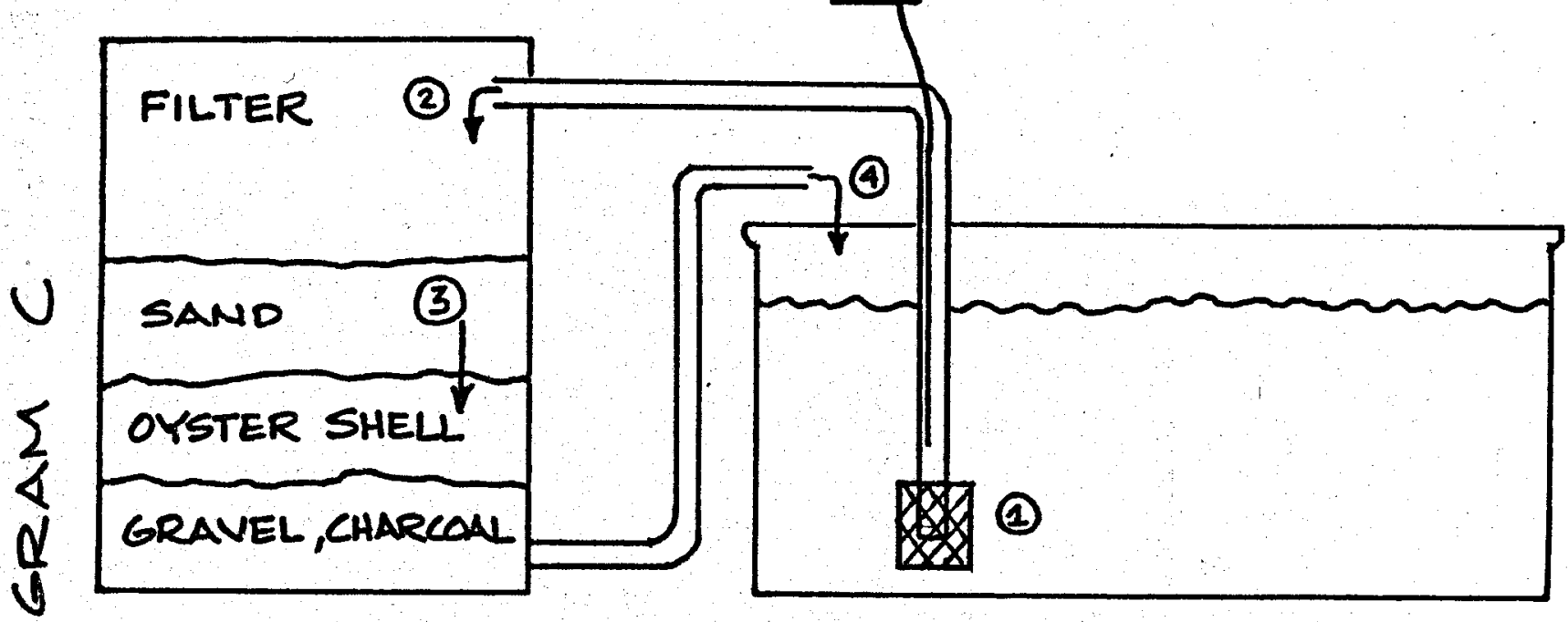

$\triangle$ AIRLIFT SYSTEM DRAWS WATER UP THROUGH PIPES AND D INTO FILTER (1) (2) LAYERS OF SAND AND OYSTER SHELL REMOVE PARTICULATES AND LOWERS PH (3) CLEAN WATER RETURNS TO CULTURE SYSTEM (4) Figure 4.

$-16-$ 
temperatures due to increased metabolism. For this reason, it is very important to keep the larval culture tank clean of detritus, to regularly change the water, and not to overfeed the larvae.

Larval culturists agree on the near-necessity of Artemia, brine shrimp, as a food source for the young prawns. The zooplankton, Moina, is used in Southeast Asta and the zooplankton of Upper $\mathrm{Klamath}$ Lake, Oregon, is also used along with brine shrimp. Because the interest in aquaculture is expanding, the world's supply of good brine shrimp cysts demands a premium price. At these prices, brine shrimp should not be wasted, and methods to obtain maximum hatch should be employed. The quality of the brine shrimp (expressed in percent hatch) varies with each batch of eggs. It must not be assumed that treatments yielding the best hatch for one batch of eggs will apply to another batch of eggs. The degree of aeration, density of eggs per liter of saltwater, and the salinity of the hatching medium affect the hatchabilities.

Most of the eggs for the brine shrimp will hatch in 24 hours, but some will take as long as 36-48 hours. A cylindrical or conical tank is the best design for hatching brine shrimp, because all the eggs are kept in suspension. Brine shrimp nauplii can easily be separated from empty cysts at feeding time. When the aeration is stopped, the empty shells float to the top and the nauplii collect at a light source. If quantities of brine shrimp eggs are to be kept for long periods of time, it is recommended that they be put into cold storage. The quality of the eggs deteriorates with heat.

Some prawn hatcheries supplement strained fish flesh for brine shrimp. The muscle fibers of raw fish filets are broken down with the use of pressurized water i (e.g., from a garden hose nozzle) and graded through a series of stainless steel sieves, figure 5. Brass soil sieves are not recommended since the percolating water may leach the heavy metals into the fish food. There is no "formula" that tells how much and what size food to feed. The size of the food should not be larger than the size of the larval prawn. The amount of feed will depend upon whether the prawns are 
PROCESSING STRAINED FISH FLESH

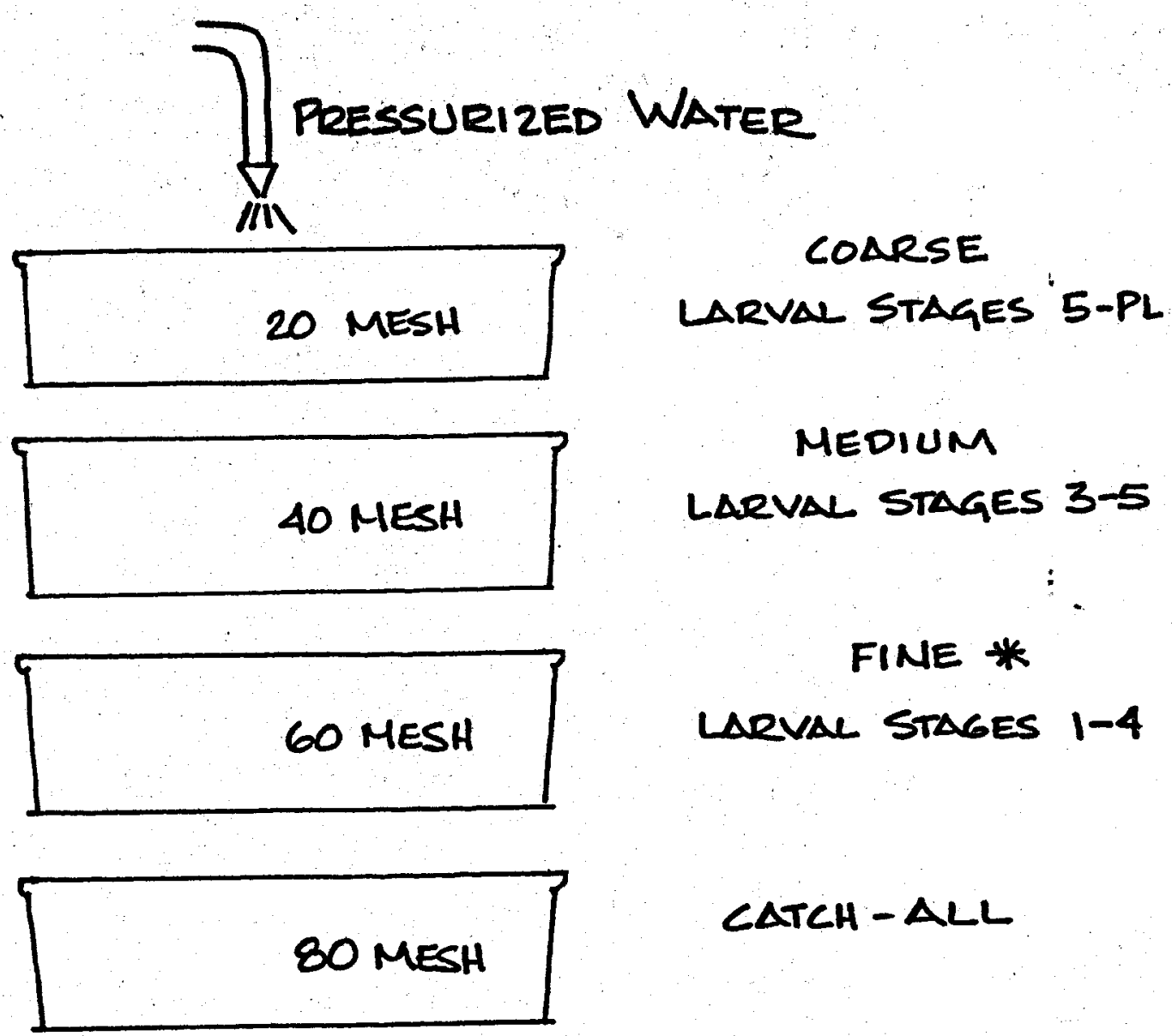

STACK SIEVES IN ORDER WITH 80 MESH ALWAYS ON THE BOTTOM, NO MATTER WHAT GRADE OF FISH IS BEING MADE.

* fine food is that which has passed the 60 MESH AND IS COLLECTED ON THE 80 MESH

Figure 5.

$-18-$ 
hungry. The larvae should be given just "enough," so that all have something to eat. Hatchery managers feed the strained fish 3-5 times daily, plus a feeding of brine shrimp. Sufficient brine shrimp is that amount which will provide larvae with food for the time when they aren't being fed fish (e.g., at night).

A good larval culturist will spend any "free" time, such as between feedings, to watch the behavior of the larvae. As with a pond manager, the hatchery manager can learn much by looking for abnormal swimming behavior, increased cannibalism, etc.

As the larvae get older, they grow at different rates. When increasing numbers of PLs are seen, shelters should be placed in the tank to make use of the vertical water column space and to cut down on prawn interaction and cannibalism. The salinity should be lowered gradually when the tank is $75 \%$ PLs. The salinity should be changed completely to fresh water when there are 90\% PLs. After the PLs have been acclimated to the fresh water, they should be transferred to the pond or to a larger tank. It is estimated that for every day the PLs are kept at high densities, $10 \%$ of the population is lost to cannibalism.

There are several methods of counting the number of PLs. The "visual standard" method, and calculation by weight are the most commonly used methods. A "visual standard" is made by placing 2,000 PLs in three liters of water. Additional buckets with the same volume of water are placed adjacent to the standard. The PLs are added to the buckets until it is estimated that they contain the same number of PLs as in the standard (Fujimoto, 1977).

\section{Hatchery Site Selection}

The selection of a site for a prawn hatchery is not as critical as for a pond. Good quality and an abundant quality of fresh water must be available. If the saltwater 
source is from a bay or ocean, the cleanest water comes from a deep well. Otherwise, problems with infestation of hydrozoans or other organisms may occur. A hatchery located inland may use a commercial sea-salt mix. The hatchery will ideally be located close to the ponds so that there is little loss of 'PLs in transportation. 


\section{Chapter IV: Problems and Perspectives}

Geothermal Application

There is a great potential for geothermal aquaculture since water temperatures : can be kept warm constantly. However, a simulated natural tropical environment will: have problems. A system such as this must have fine controls and emergency backup systems.

Areas that have geothermal water available for a prawn farm should also have a source of cold water nearby. In case of emergency such as low DO, toxicity, or excess phytoplankton, the geothermal hot water may have to be mixed with the cold in order to flush a pond to exchange "bad" water for "good." If there is no cold water, a large reservoir for cooling hot water must be used, but this method is not as efficient for flushing a pond.

The use of geothermal energy for aquaculture requires the use of electricity to run pumps, thermostatic water controls, space heaters for the hatchery, etc. A1ternate systems such as automatically triggered generators are a must. Manual controls and monitoring devices add to the complications of geothermal aquaculture. Alarm systems that warn of power failure are elaborate mechanisms, nice to have, but not necessary. The best security a farmer can have is to live on the farm site and to be aware of what is happening on the farm. Prawn farming, like all farming, is a 24-hour, sevenday-a-week job.

\section{Legalities}

Before a prawn farm can be set up, there are permits which must be obtained. Various state and federal agencies have control over different aspects of fish 
culture, a term which could include prawns. The importation and propagation of nonnative species, controls of water discharge, and disease prevention, are only a few areas of concern. It is easy to imagine the governmental agencies involved with these. In Oregon, permits must be obtained from the Oregon Department of Fish and Wildife. If prawn processing is planned, permits will be required from the Oregon Health Department.

\section{Limitations}

The biggest limitation to aquaculture is money. Many look at the maximum possible cash inflow and become starry-eyed even before considering the cost of setting up an operation or the cost of running it. Most farmers should not expect to make money in the first year. Others will "break even" in the first two years. Aquaculture can be profitable, but it is profit derived from the rigors of farming. 


\section{APPENDIX}

\section{Metric and English Conversion}

Temperature:

$$
\begin{aligned}
& \frac{9}{5} \times{ }^{\circ} \mathrm{C}+32={ }^{\circ} \mathrm{F} \\
& \frac{5}{9} \times\left({ }^{\circ} \mathrm{F}-32\right)={ }^{\circ} \mathrm{C}
\end{aligned}
$$

Length:

$$
1 \text { meter }=3.28 \text { feet }
$$

1 centimeter $=0.394$ inches

$$
\begin{aligned}
& 1 \text { foot }=0.305 \text { meter } \\
& 1 \text { inch }=2.54 \text { centimeter } \\
& 1 \text { pound }=0.454 \text { kilograms } \\
& 1 \text { gallon }=3.785 \text { liters }
\end{aligned}
$$

Weight:

1 kilogram $=2.205$ pounds

Volume:

1 liter $=0.264$ gallons 


\section{Acknowledgement}

This project was financed by a contract (76002) from the Pacific Northwest Regional Commission, Vancouver, WA 98661.

\section{References}

Fujimoto, M., T. Fujimura and K. Kato, 1977, "Pond Grow-out Systems," In Hanson, J. A. and H. L. Goodwin, (eds.), Shrimp and Prawn Farming in the Western Hemisphere, Dowden, Hutchinson \& Ross, PA., pages 237-254.

Fujimura, T., 1974, Development of a Prawn Culture Industry in Hawaii, Job Completion Report: July 1, 1969-June 30, 1972, U.S. Department of Cormerce, NOAA, NMFS.

Johnson, W. C... In press, Culture of Freshwater Prawns (Macrobrachium rosenbergii) Using Geothermal Wastewater, Proc. X World Mari. Soc.

Ling, S. W., 1969, The General Biology and Development of Macrobrachium rosenbergii (de Man), FAO Fish. Rept., 3(57): 589-606. 